\title{
Analysis on Strategies to Improve Japan's Basic Education Quality in the New Century
}

\author{
Bing Li \\ School of Politics and Public Administration \\ University of Electronic Science and Technology \\ Chengdu, P.R.China
}

\author{
Qin Li \\ School of Politics and Public Administration \\ University of Electronic Science and Technology \\ Chengdu, P.R.China
}

\begin{abstract}
It is the common aspiration of every country to enhance its education quality. In the new century, Japan's basic education puts more emphasis on training students' social viability for the future with the core of "self-reliance", "collaboration" and "creativity". This thesis mainly focuses on Japan's quality assurance mechanism for basic education, its development in building creative environment under the background of changing times, and its education quality feedback and improvement. Through exploring Japan's management strategies which assure the quality of basic education, this thesis provides some useful experience for China to improve the quality of its basic education.
\end{abstract}

Keywords-Japan's basic education; education quality; quality assurance mechanism

\section{INTRODUCTION}

In the era of rapid globalization, how will the updated technologies and reformed production mode change the education industry? Facing the future, if our basic education has been prepared in advance, and how to make children and adolescents cope with this changing reality successfully? To answer these questions, it is important for us to consider how to assure the quality of basic education. To take a close look at China's neighbor-Japan, it has been doing hard work and making useful exploration in the field of basic education upon entering the new century. It is of certain reference meaning for China to learn from Japan by exploring its philosophy of basic education from the level of education quality assurance mechanism and its strategies and quality monitoring methods used in improving the basic education quality.

\section{JAPAN'S BASIC EDUCATION QUALITY ASSURANCE MECHANISM AND FEATURES}

High quality education has become a hot spot and focus of the world's education. Hawes and Stephens believes that the quality of education consists of three elements: effectiveness, relevance, and some special factors (such as creativity, happiness, etc.), and the assurance of education quality should not only concern the national expectations of education, but also provide appropriate education and development opportunities for different individuals, so as to meet the different needs of consumers[1]. Under the quality assurance mechanism of basic education in Japan, it is the government which formulates the education goals as well as the environment to realize such goals. On the basis of the education guiding outline formulated in accordance with education goals, the government stipulates the depth and breadth of the content of primary and secondary education, which will become a standard to evaluate the quality of primary and secondary education. In monitoring the outcome, the government will be responsible for investigating the educational and academic level nationwide to give feedback on the quality of primary and secondary education. From the perspective of PDCA (Plan-Do-Check-Action), school evaluation system and education cyclic development and improvement system are established to constantly adjust the environment and goals according to feedback, so as to ensure the quality of primary and secondary education [2].

Under the pressure of globalization of assessment standardization, such as PISA and the diversification of the objects of civil society, the quality assurance of Japan's basic education has been gradually transferred from centralized ways to school-based decentralized cooperation and from localization to internationalization and globalization to strengthen its quality assurance and school supervision [3]. On the aspect of quality assurance of basic education, the biggest difference between Japan and Western countries is that the former emphasizes more on establishing the interpersonal relationship among different regions through operating schools, reflecting the Japanese style quality requirements for basic education[4]. Schools, as regional link, represent the local culture. In addition, Japan is also intended to be prepared for the future reforms on education by improving the educational environment.

\section{EducAtion Quality Assures Students' AbILITY}

\section{A. Understanding of Japan's Basic Education on Students' Ability}

Basic education is the foundation of students' future development. Faced with the rapidly changing globalization and information age, it has become the main point in education quality assurance of what kind of people to be trained. In 2005, the Central Council for Education of Japan held the meeting of "creating compulsory education in the new era" and made it clear that it is of the government's responsibility and obligation to set the goal of compulsory education and establish the education environment. Besides, the government 
is also responsible for examining the results of compulsory education and ensuring that the quality of compulsory education conforms with relative requirements [5]. In 2006, Japan revised the Education Act and established a plan to revitalize education. The new Act stipulates that "the purpose of compulsory education is to give full play to each person's ability to live independently in the society and train people to have the basic qualification to become a member of the country and the society" [6]. From the legislation level, it clarifies that the goal of compulsory education mainly involves two aspects: one is to train people to have national identity, and the other one is to train their social viability.

For the current Japanese society, the trend of aging and low birth rate requires everyone to fully play each one's ability to enhance the quality of education. Besides, Japanese students' poor performance in the international PISA test in recent years in nerves Japanese people, which raises concern about improving the quality of basic education. Faced with these changes, Japan has particularly presented in the first education revitalization plan implemented from 2007 to 2012 that its basic education should focus on respecting personality, developing ability, training students' ability to survive in society, and cultivating them to become social members who are well-cultured, professional and knowledgeable[7]. In the following second education revitalization plan implemented from 2013 to 2018 , it is specially pointed out that "in face of rapidly changing social situation, compulsory education, which is the foundation of training talents, should establish a robust safety learning net that is stronger than that of any times to train students to have world-class academic ability, awareness of norms and attitude of respecting history and culture". It also proposes four educational administrative directions that are "training social viability", "training talents to make leap forward achievement in the future", "establishing a safe learning net" and "building dynamic community relations". On such bases, it will promote, with the core of "self-reliance", "collaboration" and "creation", training students" social viability in basic education so as to ultimately establish the lifelong learning system.

\section{B. Specific Measures to Train Students' Ability}

On the basis of training students to have solid social viability, it tries to enrich the traditional culture courses, respect the diversity of individuals and the society, and foster human and social relations with the core of self-reliance and collaboration. It aims to enrich moral and human rights education and increase the opportunities for students to engage in experiencing outdoor living activities; to strengthen vocational education and to increase the chances for students to contact with other adults other than teachers and parents, so as to realize mix-age exchanges. It also tries to enhance students' awareness of future career planning, thus providing more intern opportunities for students to experience real work. Besides, it actively promotes health education on campus to effectively improve students' physique and stamina, and strengthen dietary culture education and provide guidance for school feeding to make students have good eating habits.

Japan strives to enhance students' creativity and communication skills and offers a variety of high-end learning opportunities for students to promote outstanding talent and personality development. It actively promotes science education in primary and secondary schools, trains students to have interests in science, and builds a platform for students to play their talents. In training talents with international perspective, it actively strengthens training students' foreign language skills and enhances their understanding of different cultures and their cross-cultural collaboration capabilities.

\section{THE FUnDAMENTAL ROLE OF ENVIRONMENTAL INNOVATION CONSTRUCTION}

With the coming of Industry 4.0, newer manufacturing concepts are gradually introduced into schools, and students' ability will no longer be solely decided by students' family, schools and the region they live. It is the development trend as well as an important requirement to improve the quality of basic education in the future to prepare a good environment for training future-faced talents.

\section{A. Exploration and Innovation in Combining Primary and Secondary Schools}

The original 6-3-3 year primary, secondary and high school system is changed to more flexible 5-4-3 or 5-3-4 years, and the independent education science having the primary and secondary schools combined system as the core has been gradually promoted nationwide [8]. Starting from the actual body and mind development of students, the combination of primary and secondary schools system knows better the characteristics of students without gap. Single and rigid education is eliminated from the perspective of educationreceiving parties, thus students and parents can choose in a variety of educational service [9]. It helps students to choose their level of school education in line with their level of proficiency, so as to achieve personal development. Meanwhile, it can also promote collaboration between kindergarten-primary school-secondary school-high schools, realizing successful transition of the various learning stages.

\section{B. ICT to Build Multiple Interactive Intelligent Learning Space}

Information technology tools are actively used to expand access to educational resources. The Japanese government prepares to equip everyone one information terminal in schools covering primary, secondary, high school and special support school an information terminal equipment. In the electronic materials research and development aspect, it is promoted to use electronic paper textbooks in primary and secondary schools [10]. Each school will have ICT facilitators to assist its information environment building, and use questionnaires and educational level tests to evaluate the effect of the use of school ICT. The smart learning space helps students to learn anywhere and anytime before, in and after class, and more opportunities are created for students to have interactive communication. 


\section{To Build Groups of Teachers with Continued Momentum and Vitality}

First, to gradually evaluate teachers according to their overall aspects instead of education background alone. To evaluate a teacher, interview and practical skills tests should be conducted besides the educational level tests. Limits on teachers' age should be relaxed, and teachers should also be properly evaluated based on individual social experience. Evaluations should be gradually transferred from focusing on educational level to overall aspects. Second, in order to diversify the teaching staff resources, schools can introduce social personnel who have profound social experience and excellent skills to the teaching staff. To achieve this, relevant systems should be established and the prefectural board of education can grant a special permit through examination to employ social personnel to become teachers. In addition, the number of school clerks and other supporting staffs such as associations and ICT instructors should be increased to create a platform for teachers to focus on teaching. Finally, it should achieve diversified training forms. Teachers' ability can be enhanced and human resources of teachers can be effectively explored by implementing, step by step, academic training for teachers and continuous system.

\section{The Development and Use of School Operation Association System}

The school operation association system is introduced on the basis of the "relative laws of local education administrative organization and operations" revised in June 2004. Parents and residents have certain rights and responsibilities to participate the operations of public school[11]. The second education revitalization plan specifies the goal of establishing a dynamic society with mutual aid and cooperation, increasing common schools, and continue to promote school assessment system, so as to formulate a self-regulated and organized school operation system. The school operation association will recognize the basic principle formulated by school principal, and bring forward opinions on the operation of school to the education committee and principal, as well as the use of teachers to the education committee. In addition, school's discretion can be expanded and school's management capacity can be strengthened. It is important to strengthen school's operational capacity, which is the carrier of promoting and operating the quality of basic education, in promoting the education quality.

\section{THE Engine Function of the Evaluation Part}

On the aspect of monitoring the quality of basic education, Japan has been actively participating in international tests such as PISA, aiming at establishing its own monitoring system of education quality and schools evaluation system nationwide by learning from these international tests, so as to achieve interregional improvement and circulation of education quality monitoring. The combination of large-scale academic research and school evaluation within the country makes the evaluation of education quality more standardized and more effective, gives more authoritative and professional guidance to schools, and is of great help for schools nationwide to improve education quality, playing the role of education quality evaluation engine.

\section{A. To Participate in International Tests and Look for International Gap}

Japan has been participating in international tests such as PISA and international science survey. According to the "OECD students' degree of study (PISA) 2012 survey" reported by Japan's National Institute for Educational Policy in December 2013, it shows the average score and ranking of Japan in the international PISA tests for five times. Overall, the ability of Japanese students is able to maintain the upstream level, but in 2003 and 2006, the test result was unsatisfactory, but it raised again in 2009 and 2012, presenting a V-shaped trend. The unstable performance of Japanese students in the PISA test has, to a certain extent, helped to promote reform on its basic curriculum and become an important basis to strengthen the evaluation and accountability education quality [12]

\section{B. To Monitor the National Educational and Academic Level Investigation System}

The nationwide educational and academic level investigation is a system monitoring the quality of basic education through evaluating students' study. It aims at testing students' study so as to ensure education quality and promote education level. The questionnaire not only investigates students' study on each learning subject, but also schools covering questions about learning methods, learning environment, living conditions, teaching, teachers, equipment, etc., establishing a monitoring system with credibility and high authority on the quality of basic education. Each school is required to analyze the causes of the monitoring result and propose measures to be taken for future improvement, and then release a report, which will become an important tool to help schools reach higher standards.we can see from the table 1,it's the ranking of reading test data from the school website of Kiwa primary school at Hirosima province in Japan.it gives a clearly comparison with the entire province and country.so Kiwa primary school need to according to the test data find out the proper solution to improve the quality of school. "Table I"

TABLE I. The NATIONAL EdUCATIONAL AND ACADEMIC READING TEST PASS RATES AND RANKING OF KIWA PRIMARY SCHOOL AT HIROSIMA PROVINCE IN JAPAN

\begin{tabular}{|c|c|c|c|c|}
\hline \multicolumn{5}{|c|}{$\begin{array}{l}\text { The national educational and academic test ranking } \\
\text { (test of reading ) }\end{array}$} \\
\hline Year & $\begin{array}{l}\text { Test Paper } \\
\quad A \& B\end{array}$ & 2013 & 2014 & 2015 \\
\hline \multirow{2}{*}{ National pass rates } & A & $62.70 \%$ & $72.90 \%$ & $70 \%$ \\
\hline & B & $49.40 \%$ & $55.50 \%$ & $65.40 \%$ \\
\hline \multirow{2}{*}{$\begin{array}{l}\text { Province Hirosima } \\
\text { pass rates }\end{array}$} & A & $65.80 \%$ & $75.90 \%$ & $73.80 \%$ \\
\hline & B & $52.70 \%$ & $58.30 \%$ & $69.70 \%$ \\
\hline \multirow{2}{*}{$\begin{array}{l}\text { Kiwa primary } \\
\text { school pass rates }\end{array}$} & A & $62.20 \%$ & $73.50 \%$ & \multirow{2}{*}{$\begin{array}{l}\text { Not being } \\
\text { released ye }\end{array}$} \\
\hline & B & $47.10 \%$ & $55.20 \%$ & \\
\hline
\end{tabular}

(Source: data sorting according to the report of Japan's National Institute for Educational Policy in 2015 and Hirosima's education Institute homepage and Kiwa primary school website http://www.onomichi.ed.jp/yoshiwa-e/) 


\section{The Self-evaluation and External Promotion of School Can Strengthen Its Function and Role Awareness As the Subject in Education Quality Assurance}

From 2002, Japan requires in the benchmark setting of primary and secondary schools that schools have the obligation to disclosure the result of self-evaluation and the results. In 2006, the evaluation of compulsory education schools was formed, and has been improving until 2010. In school evaluation, the school evaluation guidebook stipulates the implementation system, method, and the proportion of selfevaluation and external evaluation. The local government provides budgetary and systematic support for schools' selfevaluation, the province will, based on actual situation, provide support for external evaluation, and the Ministry of Education will provide student guidance data through various kinds of investigation.

\section{ENLIGHTENMENT ON CHINA}

To make a comprehensive survey on Japan's effort on promoting the quality of basic education, it can be seen that its basic education quality assurance system is a perfect and circulatory system from every aspect of standard setting, process implementation, and the setup of nationwide improvement and feedback mechanism. Every link is progressive and closely integrated.

- To establish education quality standards which specify the development vision and requirements of training students' ability, and lead the direction of improvement of education quality. Japan establishes the education goals and requirements from legislative level, helps students to know themselves with the orientation of valuing social viability training, cultivates students to establish the relationship between people and society, and train students to have the ability to solve problems with tools. It has become the focus of enhancing students' overall quality and enable them to face the future. On the philosophy of education, Japan values international standards and holds that the promotion of education quality does not only merely limited to student academic achievement, but should also be embodied in preparing students to face the rapidly changing future based on three concepts, that are "self-reliance", "collaboration" and "creativity".

- To develop good strategy and implementation plan to achieve maximum quality results. It makes education development strategy in consistent with the ultimate goal, deems the promotion of education quality as a dynamic process, and continuously pushes forward and adjusts the national strategic plan to adapt to the future development of education, promotes diversity and innovation of school education, and monitors education performance and intervenes timely. By doing so, the plan, process, result, feedback and adjustment are all closely combined.

- To emphasize on establishing a innovative environment for basic education. It promotes the flexible combination of primary and secondary schools system and the establishment of ICT environment to provide more personalized and diversified educational service for education receivers, so as to achieve good transition of education stages and create a platform for teachers to focus on teaching. To pay attention to the pluralistic participation to promote the quality of education, and constantly increase the opportunities for third parties to participate in the development of education.

- To draw on international standards effectively and develop localized quality monitoring system. To participate in international tests actively and accumulate comparable information and data. By building a system to monitor the quality of educational and academic level nationwide and mass inter-schools evaluation, a virtuous circle of implementing and improving education plan will be formed to provide real and reliable while systematic and scientific information and data support for future education reform.

\section{REFERENCES}

[1] Hawes, H., \& Stephens, D. Questions of quality:. Primary education and development [M] Harlow: Longman, 1990.

[2] [2] [5] [6] [11] Ministry of Education White Book 2014, Ministry of Education White Book 2013, basic material of learning quality assurance and the result evaluation 2012 [R] http:. // Www .mext.go.jp / a_menu / a002.html

[3] Omomo Toshiyuki. the quality assurance of governance reform and education, evaluation on education assurance and various learning results $[R]$. education research center of Tokyo University and education school affiliated to the department of education symposium, 2014.102 107

[4] Alimoto Msahiro. The meaning to introduce the concept of quality assurance of Japan's compulsory education-from discussion of quality assurance overseas. [J] National Institute for Educational Policy Research summary 134. $2005.81 \sim 85$

[5] Li Jingxie. Review on Japan's second education revitalization [J]. World Education Information, 2013, (18) 25-28

[6] Sakano Shinji. Research on the development of compulsory education policy [J]. summary of the education department of Tamagawa University. 2014,38 to 42

[7] Zhang Dewei. Policy trend of Japan's modern education system reform [J]. Foreign Education, 2013. (12) 8-9

[8] $\mathrm{Xu}$ Han translate and edit, Japanese primary and secondary schools will use electronic textbook [J]. World Education Information, 2015 (14)

[9] Tan Jianchuan. What has PISA changed-to review Japan's education reform from educational level evaluation $[\mathrm{J}]$ Journal of Teacher Education. 2014.10.45 46 